\title{
Kronik pelvik ağrı sendromu/tip 3 prostatitli infertil hastaların serum ve ejakülat inhibin B seviyelerinin değerlendirilmesi
}

\section{The evaluation of serum and ejaculate inhibin B levels in infertile patients with chronic pelvic pain syndrome/type 3 prostatitis}

\author{
Usupbaev Akylbek¹, Rysbaev Bolotbek', Stambekova Kanyshai¹, Baisalov Mirbek', Kuzebaev Ruslan', \\ Jandraliev Ramis
}

\section{öz}

\begin{abstract}
AMACุ: Spermatogenezin hormonal düzenlenmesi son derece önemli olup inhibin B gibi Sertoli hücrelerinin etkinliğini yansıtan peptidlerin seviyesi özelikle önem arzetmektedir. Follikül uyarıcı hormon (FSH) ile karşılaştırıldığında inhibin B'nin erkek fertilite bozukluğunu ortaya koymada daha erken bir endokrin belirteç olduğu gösterilmiştir. Bu çalışmanın amacı kronik pelvik ağrı sendromu/tip 3 kronik prostatitli infertile olgular ile sağlıklı erkek olgularda ejekülat ve surumdaki inhibin B seviyelerinin araștırılmasıdır.

GEREÇ VE YÖNTEM: Bu çalışmada yaşları 22-45 yıl arasında olan KPAS/ tip 3 kronik prostatit tanılı 136 olgu değerlendirilmiştir. Bütün hastalar iki gruba ayrılmışlardır. Birinci grup KPAS/Tip 3A kronik prostatitli 96 hastayı içermiștir. İkinci grup ise KPAS/Tip 3B tanılı 40 hastayı içermiștir. Kontrol grubu ise yaş eşleştirilmiş 20 fertil erkekten oluşmuştur.

BULGULAR: Bu çalışmanın sonuçları KPAS'lı olgularda inhibin B'nin serum seviyelerinin fertili gruba göre $(307,7 \pm 81,5 \mathrm{pg} / \mathrm{mL})$, anlamlı olarak daha düşük seviyelerde $(105 \pm 27,9 \mathrm{pg} / \mathrm{mL})$ olduğunu göstermiştir $(\mathrm{p}<0,001)$. Aynı zamanda, inhibin B seviyelerinin tip $3 \mathrm{~A}$ ve tip $3 \mathrm{~B}$ arasında anlamlı olarak farklı olmadığını tespit ettik (sırasıyla $106 \pm 29 \mathrm{pg} / \mathrm{mL}$ ve $101,6 \pm 24,2 \mathrm{pg}$ / $\mathrm{mL}, \mathrm{p}>0,05$ ). Benzer sonuçlar sperm konsantrasyonu ve inhibin $B$ seviyeleri sözkonusu olduğunda KPAS ve sağlıklı kontrol grubu arasında saptanmıştır (KPAS'ta 96,1 $\pm 30,9 \mathrm{pg} / \mathrm{mL}$, sağlıklı kontrol grubunda 303,5 $\pm 75,4 \mathrm{pg} / \mathrm{mL}$, $\mathrm{p}<0,001)$

SONUÇ: Sonuçlarımıza göre inhibin B’nin serum ve sperm plazma sonuçlarının KPAS'lı olgularda fertil kontrol grubuna göre anlamlı olarak daha düşük olduğu görülmüştür. Aynı zamanda bu belirtecin tip $3 \mathrm{~A}$ ve $3 \mathrm{~B}$ hastaları arasında anlamlı farklllık göstermediği saptanmıştır.

Anahtar Kelimeler: İnhibin B, erkek infertilitesi, kronik pelvik ağr sendromu, prostatit
\end{abstract}

${ }^{1}$ Pre- and Post-graduate Training Department of Urology and Andrology, I.K. Akhunbaev Kyrgyz State Medical Academy; 1 Togolok Moldo St., Bishkek, 720020, Kyrgyz Republic

'Kyrgyz Research Center for Human Reproduction, Kyrgyz Republic, 720028, Bishkek, 7-14/1

Yazısma Adresi/ Correspondence:

Rysbaev Bolotbek

Pre- and Post-graduate Training Department of Urology and Andrology, I.K. Akhun baev Kyrgyz State Medical Academy; 1 Togolok Moldo St., Bishkek, 720020, Kyrgyz Republic

Tel:

+996700522259

E-mail: bolot_rysbaev@mail.ru

Gelis/ Received: $\quad 10.06 .2020$

Kabul/ Accepted: $\quad 17.06 .2020$

\section{ABSTRACT}

OBJEKTIVE: The study of the hormonal regulation of spermatogenesis is important, in particular, the level of peptides that directly reflect the Sertoli's cells activity, which include inhibin B. It demonstrates that in comparison with $\mathrm{FSH}$, inhibin $\mathrm{B}$ has been shown to be an earlier endocrine marker of fertility disorder. The aim of our research was to study the inhibin B content in the blood serum and ejaculate of healthy men and men from infertile couples suffering from chronic pelvic pain syndrome/Type 3 prostatitis (CPPS/Type 3 prostatitis).

MATERIAL AND METHODS: We examined 136 infertile patients with CPPS at the age of 22-45 years old. All patients were divided into 2 groups. The 1st group included 96 patients with CPPS/Type 3A category. The 2nd group included 40 patients with CPPS/Type 3B. The control group consisted of 20 healthy fertile men, equitable in age.

RESULTS: The results of our research indicate that the level of inhibin B in the blood serum in the general group of patients with CPPS, amounting to $105 \pm 27.9 \mathrm{pg} / \mathrm{mL}$, was significantly lower compared to fertile men $(307.7 \pm 81.5 \mathrm{pg} / \mathrm{mL}, \mathrm{p}<0.001)$. At the same time, we did not find significant differences in the concentration of this biomarker among patients of type $3 \mathrm{~A}$ and type $3 \mathrm{~B}$ groups $(106 \pm 29 \mathrm{pg} / \mathrm{mL}$ and $101.6 \pm 24.2 \mathrm{pg} / \mathrm{mL}$, respectively, $p>0.05$ ). Similar data were obtained with respect to the concentration of sperm inhibin B, the level of which among infertile men with CPPS, amounting to $96.1 \pm 30.9 \mathrm{pg} / \mathrm{mL}$, was significantly lower in comparison with the group of healthy men $(303.5 \pm 75.4 \mathrm{pg} / \mathrm{mL}, \mathrm{p}<0.001)$.

CONCLUSIONS: According to our data, the level of inhibin B in blood serum and sperm plasma in patients with chronic nonbacterial prostatitis was significantly lower compared to fertile men. At the same time, we did not find significant differences in the concentration of this biomarker among patients of IIIA and IIIB groups.

Key words: inhibin B, male infertility, chronic pelvic pain syndrome, prostatitis

\section{Gíniș}

Erkek infertilitesi, bir erkeğin normal bir kadın partner varlığında korunmasız düzenli cinsel ilişkiye rağmen, bir yilın sonunda konsepsiyon meydana gelmemesi veya çocuk sahibi olamaması olarak tanımlanmaktadır. ${ }^{[1]}$ Androlojinin önemli alt başlıklarından biri olan infertilitenin çiftlerde sosyal çekilmeler ve özgüven kaybına neden olduğu ve bu alanda medikal araştırmaların giderek artan oranlarda olmak üzere devam ettiği görülmekedir. Bunun haricinde 
ülkelerden ülkelere değişmek üzere infertilitenin evli çiftlerin \%7-10’unda görüldügü anlaşılmaktadır. İnfertil çiftlerde etiyolojide izole kadın faktörü \%40-50, izole erkek faktörü \%30 oranında yer alırken her iki cinste sorun olma olasılığı \%20 civarındadır. ${ }^{[2-4]}$ Erkek infertilite faktörleri içerisinde inmemiş testis, varikosel, hipogonadotropik hiogonadizm gibi hormonal bozukluklar, genetik nedenler, metabolik ve çevresel hastalıklar ile enfeksiyonlar yer almaktadır. İnflamatuar faktörler genital ve üriner sistemle ilişkili olmak üzere infertiliteye neden olabilmektedirler. ${ }^{[1,5]}$

Spermlerde anormal bir patolojinin olması durumunda Sertoli hücreleri üzerinde yer alan reseptörlerde fonksiyon bozukluğu olacaktır. Bu durum Seminifer tübüllerde intrasellüler testosteronun azalması ve sperm matürasyon sürecinde bozukluğa yol açabilecektir. ${ }^{[6,7]}$ Sertoli hücrelerinin fonksiyonel aktivitesini gösteren belirteç inhibin B isimli peptittir. İnhibin B gonadlara parakrin olarak etki etmekte olup selektif olarak ön hipofizde yer alan FSH'ın salınımını bloke etmektedir. Son dönemlerde Sertoli hücreleri tarafından üretilen inhibin B ve infertilite ilişkisi ile ilgili çok sayıda çalışma yer almaktadır. ${ }^{[8-10]}$ İnhibin B seviyelerinin spermatogenez bozukluğu olanlarda infertilite problemi olmayanlara göre daha düşük düzeylerde olduğu bildirilmiştir. ${ }^{[11]}$

Bu çalışmanın amacı kronik pelvik ağrı sendromu (KPAS)/ tip 3 kronik prostatitli infertil olgular ile sağlıklı erkek olgularda ejekülat ve serumdaki inhibin B seviyelerinin araştırılmasıdır.

\section{GEREÇ VE YÖNTEM}

$\mathrm{Bu}$ çalışmada yaşları 22-45 yıl arasında değişen KPAS/tip 3 kronik prostatitli toplam 136 olgu ve 20 olgudan oluşan kontrol grubu değerlendirilmiştir. KPAS/tip3 prostatit tanısı Ulusal Sağlık Enstitüsü 1995 yılı kriterleri gözönünde bulundurularak yapılmıştır. ${ }^{[12]}$ Buna göre hastalar KPAS/ tip 3 prostatit tanısı olanlar $(\mathrm{n}=136)$ ve kontrol grubu $(\mathrm{n}=20)$ olmak üzere iki gruba ayrılmışlardır. İlk grup ayrica KPAS/tip 3A kronik prostatit $(\mathrm{n}=96)$ ve KPAS/tip 3B kronik prostatit $(n=40)$ olmak üzere iki alt gruba ayrılarak incelenmişlerdir. Hastalar ayrıntılı tıbbi öykü, fizik muayene, rutin hematolojik ve biyokimyasal tetkikler, tam idrar tetkiki ve gerektiğinde üriner sistem ultrasonografisi ile değerlendirilmişlerdir.

Ejakülatın makroskopik ve mikroskopik incelenmesi WHO 1999 kriterlerine göre yapılmıştır. Semen analizinde ejakülat volümü, total sperm sayısı, sperm konsantrasyonu, sperm motilitesi, sperm viabilitesi ve morfolojisi değerlendirilmiştir. İnhibin B düzeyleri HumaReader HS Human apparatus (Germany) kullanılarak enzim immunoassay yöntemiyle belirlenmiştir. Bu teknikle inhibinB referenas aralığı 25-325 pg/mL (median 166 pg/mL) olarak kabul edilmektedir.

İstatistiksel değerlendirme için Statistica 6.0 standart paket programı kullanılmışııı. Gruplar arasındaki farklılıkların değerlendirilmesinde $\mathrm{Z}$ ve Mann-Whitney nonparametrik testler ile parametrik Student t-testi kullanılmıştır. Korelasyon analizleri için $\mathrm{r}$ Spearman korelasyon katsayısı kullanılmışır; $\mathrm{p}<0,05$ değerleri anlamlı olarak kabul edilmiştir.

\section{BULGULAR}

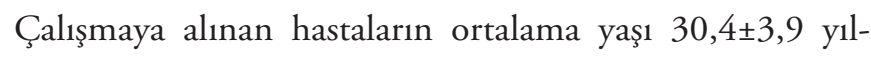
d. Grup 1'de yer alan KPAS/tip 3A ve KPAS/tip 3B'deki oratalama yaşlar ise sırasıyla $30,4 \pm 4,3$ yıl ve $30,1 \pm 2,4$ yıldi. Kontrol grubunda yer alan olguların ortalama yaşı ise $30 \pm 4,5$ yıldır.

Bu çalışmanın sonuçlarına göre serum inhibin B seviyeleri KPAS/Tip 3 kronik prosttaitli olgularda $105 \pm 27,9$ pg/mL olarak saptanırken bu oran fertil olguların olduğu kontrol grubunda $307,7 \pm 81,5 \mathrm{pg} / \mathrm{mL}$ olarak saptanmıştır. İki grup arasındaki bu fark istatistiksel olarak anlamlı idi $(\mathrm{p}<0,001)$. Ancak, inhibin B seviyeleri tip $3 \mathrm{~A}$ ve tip $3 \mathrm{~B}$ arasında s1rasiyla $106 \pm 29 \mathrm{pg} / \mathrm{mL}$ ve $101,6 \pm 24,2 \mathrm{pg} / \mathrm{mL}$ olarak tespit edilmiş olup bu farkın istatistiksel olarak anlamlı olmadığı görülmüştür $(p>0,05)$.

Benzer sonuçlar sperm konsantrasyonu açısından da elde edilmiştir. KPAS/tip 3 prostatiti olan infertil olgularda inhibin B seviyesi 96,1 $\pm 30,9 \mathrm{pg} / \mathrm{mL}$ olarak saptanırken bu oran sağlıklı kontrol grubunda 303,5 $\pm 75,4 \mathrm{pg} / \mathrm{mL}$ olarak saptanmıştır. Buna göre infertil KPAS/tip 3 prostatitli olgularda inhibin B seviyesinin anlamlı olarak daha düşük olduğu tespit edilmiştir $(\mathrm{p}<0,001)$. Semen sıvısında inhibin $\mathrm{B}$ seviyelerinin tip $3 \mathrm{~A}$ ve tip $3 \mathrm{~B}$ arasında anlamlı olarak farklı olmadığı görülmüştür (Tablo 1).

Spermatogenezle ilişkili bozukluklar açısından da inhibin B seviyeleri analiz edilmiştir. İnhibin B seviyelerinin serum düzeylerinin normospermik olgularda en yüksek olacak şekilde $21,4 \pm 29,6 \mathrm{pg} / \mathrm{mL}$ olduğu saptanmıştır. Patolojik sperm değerleri olan olgularda ise inhibin $\mathrm{B}$ seviyeleri anlamlı olacak şekilde düşük saptanmıştır $(\mathrm{p}<0,01-0,001)$. Buna karşın, oligoospermi, astenoospermi ve teratozoospermi olguları arasında inhibin B seviyeleri açısından anlamlı fark saptanmamıştır $(p>0,05)$. Sperm plazmasında yapilan incelemede inhibin $B$ seviyelerinin oligospermik $(80,5 \pm 23,8 \mathrm{pg} / \mathrm{mL})$ ve teratospermik $(92,8 \pm 39,3 \mathrm{pg} /$ $\mathrm{mL}$ ) olgularda en düşük seviyede olduğu tespit edildi. Astenospermi $(96,5 \pm 36,4 \mathrm{pg} / \mathrm{mL}, \mathrm{p}<0,01)$ ve normospermi 
Tablo 1. Infertilite ve KPAS/tip 3 kronik prostatit tanısı olanlar ile kontrol grubuna ait serum ve seminal sıvı inhibin B düzeyleri

\begin{tabular}{|c|c|c|c|c|c|}
\hline & Kontrol & Genel grup & $K P A S / 3 A$ & $K P A S / 3 B$ & $P$ \\
\hline $\begin{array}{l}\text { Serum inhibin } \\
\text { B düzeyi, } \mathrm{pg} / \mathrm{mL}\end{array}$ & $307,7 \pm 81,5$ & $105 \pm 27,9 * *$ & $106 \pm 29 * *$ & $101,6 \pm 24,2 * *$ & $\mathrm{n} / \mathrm{a}$ \\
\hline $\begin{array}{l}\text { Ejakülat inhibin } \\
\text { B düzeyi, pg/mL }\end{array}$ & $303,5 \pm 75,4$ & $96,1 \pm 30,9 * *$ & $96,8^{* *}$ & $93,8 \pm 29,2 * *$ & $\mathrm{n} / \mathrm{a}$ \\
\hline
\end{tabular}

n/a, güvenilir olmayan farklııklar; ** - p<0.01, Kontrol grubuna göre anlamlı farklııklar; KPAS, kronik pelvik ağıı sendromu.

$(105,4 \pm 18,9 \mathrm{pg} / \mathrm{mL}, \mathrm{p}<0,01)$ olgularında ise yüksek oranları tespit edildi.

Korelasyon analizlerinde serum inhibin B seviyelerinin KPAS/tip 3 prostatitli genel populasyondaki dejeneratif formların içeeriği ile $(\mathrm{r}=-0,19, \mathrm{p}<0,02)$ tip $3 \mathrm{~A}$ olgularındaki dejeneratif formların içeriği $(r=-0,20, p<0,05)$ ve tip 3B olgularındaki dejeneratif formların içeriği $(r=-0,35$, $\mathrm{p}<0,05)$ ile ilişkili olduğu görüldü. Ayrıca inhibin B'nin tip 3B olgularında sperm konsantrasyonu ile anlamlı olacak şekilde poizitif yönde korelasyon gösterdiği saptandı $(\mathrm{r}=0,36, \mathrm{p}<0,05)$.

Sperm plazmasında inhibin B'nin sperm karakteristikleri ile ilgili daha belirgin ilişkiler göze çarpmışır. Buna göre KPAS/tip 3 prostatitli olgularda sperm inhibin B seviyesi ile sperm konsantrasyonu $(r=0,38, p<0,001)$, dejeneratif formların varlığı ile inhibin B seviyeleri arasında $(g=-0,21$, $\mathrm{p}<0,01)$ dikkate değer ilişkiler saptanmıştır.

Tip 3A grubunda yer alan hastalarda sperm inhibin B seviyeleri total sperm sayısı $(r=0,23, p<0,02)$, sperm konsantrasyonu $(r=0,37, p<0,001)$, motilite $(A+B, \%: r=0,26$, $\mathrm{p}<0,01 ; \mathrm{D}, \%: \mathrm{r}=-0,23, \mathrm{p}<0,02)$ ve dejeneratif formların varlığ grubunda ise sperm plazma inhibin $B$ seviyeleri sperm sayis1 $(r=0,45, p<0,05)$ ve motilite $(A+B, \%: r=0,35, p<0,05$; for $D, \%: r=-0,46, p<0,01)$ ile anlamlı olacak şekilde ilişkiliydi

\section{TARTIȘMA}

$\mathrm{Bu}$ çalışmada inhibin B seviyelerinin sperm konsantrasyonu ve sperm sayısı ile ilişkisini gösterdik. Bu sonuçlar, inhibin B seviyeleri ve spermatogenez üzerine yapılan daha önceki çalışmalarla uyumlu olacak şekilde inhibin B seviyesinin Sertoli hücresi yeterliliğini ve spermatogenezi göstermede önemli bir belirteç olduğu ortaya koymaktadır. ${ }^{[7,13-15]}$ Araştırmacılar küçük olgu sayısına sahip gruplarda düşük inhibin B seviyelerinin azoospermik, testiküler bozukluk ve infertilitesi olan olgularda fertil kontrollere göre daha düşük olduğunu göstermişlerdir. ${ }^{[13,16]}$ Yakın dönemde 349 olguluk bir çalışmada inhibin B ile sperm konsantrasyonu arasında pozitif anlamlı korelasyon saptandığı bildirilmiştir. $^{[17]}$ Yine inhibin B ile sperm konsantrasyonu ve testis volümü açısından normal olgular ve bozulmuş spermatogenezi olan olgular açısından anlamlı farklar olduğu bildirilmiştir. ${ }^{[18]}$ Erkek üreme sisteminde inhibin B seviyeleri infertil olgularda, hem prognostik öneme sahip hem de bilimsel ve pratik olarak tanısal değer taşımaktadır. Yapılan birkaç çalışmada İnhibin B seviyesinin oligozoospermi, azoospermia ve normospermi olgularında farklı seviyelerde olduğu belirtilmiştir. İnhibin B seviyelerinin oligoospermi/ azoospermisi olan infertile olgularda normospermik olgulara göre anlamlı olarak daha düşük seviyede olduğu bildirilmiştir. ${ }^{[11,19,20]}$ İnhibin B seviyelerinin serum düzeylerinin spermatogenez kalitesi ve Sertoli hücresi fonksiyonlarını göstermede önemli bir belirteç olduğu gösterilmiştir. ${ }^{[21]}$ Çalışmamızda da infertile olgularda inhibin B seviyesinin kontrol grubuna göre daha düşük olduğu saptanmıştır.

İnhibin B seviyesini ölçmenin bir diğer avantajı tüm testis dokusunun fonksiyonunu yansıtmasıdır. Bilindiği üzere testis biyopsisi bütün testis fonksiyonlarını yansıtmamaktadır. Günümüzde testiküler sperm ekstraksiyonu için yapılan multipl testiküler biyopsilerde spermatogenezin tamamı için değişken verilerin elde edilebileceği gösterilmiştir. ${ }^{[13,22]}$ Serum inhibin B seviyelerinin testiküler bozukluğu olanlarda kontrol grubu ile karşılaştırıldığında anlamlı olacak şekilde daha düşük düzeylerde olduğu bunun gibi spermatogenezin klasik göstergeleri olan sperm konsantrasyonu, total sperm sayısı ve testis volümü ile de pozitif yönde korele olduğu saptanmıştır. ${ }^{[7,23]}$ İnhibin B seviyelerinin normal spermatogenezli olgularda Sertoli Cell Only sendromu olan olgular ile bozulmuş sperm matürasyonu olan olgulara göre daha yüksek olduğu gösterilmiştir. ${ }^{[24]}$ Azoospermi ya da oligospermisi $(<2 \mathrm{milyon} / \mathrm{mL})$ olan olguların düşük inhibin $B$ seviyelerinin testis hasarını göstermede yüksek FSH değerlerinden daha etkili olduğu bulunmuştur. ${ }^{[22]}$ Bundan dolayı bazı araştırmacılar inhibin B seviyelerini epididimdem perkütan aspirasyon için sperm motilitesini öngörmede belirteç olarak kullanmışlardır. ${ }^{[25]}$ İnhibin B'nin spermatogenetik bozuklukları ortaya koymadaki tanısal değeri iyi görünmektedir. Bu durum inhibin B'nin seminifer tübülüslerin doğrudan bir ürünü olmasıyla açıklanabilir. Seminifer 
tübülüslerin bir ürünü olduğu için spermatogenezin ileri aşamaları ile sekresyonu uyarılmaktadır. ${ }^{[20]} \mathrm{Bu}$ sonuçlar insanlarda inhibin B'nin Sertoli hücreleri bütünlüğü ve spermatogenez normal işleyişi açısından şimdiye kadar ortaya konulmuş çalışmaların gösterdiği üzere önemli bir belirteç olduğunu ifade etmektedir. ${ }^{[26,27]}$ Testiste, seminifer tübülüs ya da Sertoli hücreleri yapısını etkileyen inflamatuar olaylar inhibin B düzeylerini değiştirebilmektedir.

Prostatit kelime anlamı olarak prostat bezinin inflamasyonu olsa da geleneksel olarak üriner sistem semptomları, enflamasyon, prostat kökenli ağrı ve etiyopatogenezi tam olarak anlaşılamayan klinik tabloyu ifade etmek için kullanılmaktadır. Akut bakteriyel prostatit, kronik bakteriyel prostatit, KPAS ve tip 4 prostatit olmak üzere dört tip prostatit bulunmaktadır. Tüm prostatitlerin \%90-95'ini oluşturan KPAS, tedavi ve etiyopatogenezindeki zorluklar ve belirsizlikler nedeniyle zor bir grubu oluşturmaktadır. Erkeklerin yaklaşı \%30'unun hayatlarının bir döneminde bu semptomları gösterdikleri ortaya konulmuştur. ${ }^{[28]}$ Genelde kronik prostatitlerin infertilite ile olan ilişkileri tartışmalı olarak kalmaktadır. Li ve arkadaşlarının çalışmalarında infertilite nedeniyle değerlendirilen 534 olgu incelenmiş olup bu olgular arasında prostatit insidansı \%39,1 ( $\mathrm{n}=209)$ olarak tespit edilmiştir. ${ }^{[29]}$ Prostatitler antisperm antikorlar, oksidatif hasar, TNF- $\alpha$ ve IL-1, IFN- $\gamma$ artışı ve obstrüksiyona bağlı olarak sperm fonksiyonlarını bozabilmektedir. Bu durumda teorik olarak bozulan semen parametreleri inhibin B seviyelerini etkileyecektir. Literatürde infeksiyonla ilişkili olmak üzere epididmoorşit modelinde inhibin B seviyelerinin değiştiği gösterilmiştir. ${ }^{[30]}$ Çalışmamızda da infertil prostatitli olgularda inhibin B seviyelerinin kontrol grubuna göre daha düşük olduğu ortaya konulmuştur.

\section{SONUÇ}

Çalışmamızın bulgularına göre inhibin B'nin serum ve sperm plazma seviyelerinin KPAS/tip 3 prostatitli olgularda fertil olgulara göre anlamlı olacak şekilde daha düşük olduğu görülmüsstür. Aynı zamanda çalışmamızda, bu belirtecin tip 3A ve tip 3B arasında anlamlı olarak farklı olmadığını tespit ettik. İnhibin B seviyeleri değerlendirildiğinde spermatogenez bozukluğunun tipine göre KPAS/ tip 3 prostatitli olgularda normospermiklerde daha yüksek olduğu saptandı. KPAS/tip 3 prostatitli olgularda oligo ya da teratozoospermili olgularda ise en düşük seviyede olduğu gösterildi. Bu çalışmada inhibin B seviyelerinin spermatogenezle korele olduğu ortaya konulmuştur. Ayrıca çalışmamız sonuçlarına göre inhibin B'nin spermatogenezi ortaya koymada iyi bir endokrin belirteç olduğu söylenebilir.
Etik Kurul Onayı

Çalışma, Helsinki Deklarasyonuna uygun olarak yürütülmüştür.

Hakem Değerlendirmesi

Dış bağımsız

Çıkar Çatışması

Yazarlar çıkar ilişkisi olmadığını beyan etmişlerdir.

Finansal Destek

Herhangi bir mali destek alınmamıştır.

\section{Ethics Committee Approval}

The study was conducted in accordance with the Declaration of Helsinki.

\section{Peer-review}

Externally peer-reviewed.

Conflict of Interest

No conflict of interest was declared by the authors.

Financial Disclosure

No financial support has been received.

\section{KAYNAKLAR}

1. Jungwirth A, Diemer T, Kopa Z, Krausz C, Minhas S, Tournaye H. E. A. U. Guidelines on Male Infertility. 2018;6-7. https://uroweb.org/wp-content/ uploads/EAU-Guidelines-on-Male-Infertility-2018-large-text.pdf

2. Hill JA, Cohen J, Anderson DJ. The effects of lymphokines and monokines on human sperm fertilizing ability in the zonafree hamster egg penetration test. Am J Obstet Gynecol 1989;160:1154-9. [CrossRef]

3. Barratt CLR, Bolton $A E$, Cooke ID. Functional significance of white blood cells in the male and female reproductive tract. Hum Reprod 1990;5:639-48. [CrossRef]

4. Krausz C, Mills C, Rogers S, Tan SL, Aitken RJ. Stimulation of oxidant generation by human sperm suspensions using phorbol ester and formly peptides: relationships with motility and fertilization in vitro. Fertil Steril 1994;62:599-05. [CrossRef]

5. Aşçı R. Subfertil erkeğin değerlendirilmesi. İçinde: Aşçı R, Çayan S, Erdemir F, Orhan I, Yaman Ö, Usta MF, Kendirci M, Ekmekçioğlu O, Kadıoğlu A, editörler. Erkek Üreme Sistemi Hastalıkları ve Tedavisi. Istanbul Tıp Kitabevi 2013. s.199-215.

6. Chong YH, Pankhurst MW, McLennan IS. The Daily Profiles of Circulating AMH and INSL3 in Men are Distinct from the Other Testicular Hormones, Inhibin B and Testosterone. PLoS One 2015;10:e0133637. [CrossRef]

7. Anawalt BD, Bebb RA, Matsumoto AM, Groome NP, Illingworth PJ, McNeilly AS, Bremner WJ. Serum inhibin level reflect Sertoli's cells function in normal men and men with testicular dysfunction. J Clin Endocrinol Metab 1996;81:3341-5. [CrossRef]

8. Anderson RA, Sharpe RM. Regulation of inhibin production in the human male and its clinical applications. Int J Androl 2000;23:136-44. [CrossRef]

9. Krause W, Bohring C. Inhibin B as a marker of spermatogenesis. A new dimension in andrology. Hautarzt 2002;53:5-10. [CrossRef]

10. Anderson A-M, Muller J, Skakkebaek NE. Different roles of prepubertal and postpubertal germ cells and Sertoli cells in the regulation of serum inhibin B levels. J Clin Endocrinol Metab 1998;83:4451-8. [CrossRef]

11. Datta A, Nayini K, Eapen A. Serum inhibin-B may predict successful sperm retrieval in azoospermic men with normal gonadotropin and testosterone levels. Hum Reprod 2012;27.

12. Nickel JC, Nigro M, Valiquette L, Anderson P, Patrick A, Mahoney J, et al. Diagnosis and treatment of prostatitis in Canada. Urology 1998;52:797802. [CrossRef]

13. Wosnitzer M, Goldstein M, Hardy MP. Review of Azoospermia. Spermatogenesis 2014;4:e28218. [CrossRef]

14. Calogero AE, Gullo G, La Vignera $S$, Condorelli RA, Vaiarelli A. Myoinositol improves sperm parameters and serum reproductive hormones in patients with idiopathic infertility: a prospective doubleblind randomized placebo-controlled study. Andrology 2015;3:491-5. [CrossRef]

15. Grunewald S, Glander HJ, Paasch U, Kratzsch J. Age-dependent inhibin $\mathrm{B}$ concentration in relation to $\mathrm{FSH}$ and semen sample qualities: A study in 2448 men. Reproduction 2013;145:237-44. [CrossRef] 
16. Frydelund-Larsen L, Krausz C, Leffers $H$, Andersson AM, Carlsen $E$, Bangsboell S, et al. Inhibin B: a marker for the functional state of the seminiferous epithelium in patients with azoospermia factor $C$ microdeletions. J Clin Endocrinol Metab 2002;87:5618-24. [CrossRef]

17. Jensen TK, Andersson AM, Hjollund NH, Scheike T, Kolstad H, Giwercman $A$, et al. Inhibin $B$ as a serum marker of spermatogenesis: correlation to differences in sperm concentration and follicle-stimulating hormone levels. A study of 349 Danish men. J Clin Endocrinol Metab 1997;82:4059-63. [CrossRef]

18. Yalti S, Gürbüz B, Fiçicioglu C. Serum levels of inhibin B in men and their relationship with gonadal hormones, testicular volume, testicular biopsy results and sperm parameters. J Obstet Gynaecol 2002;22:64954. [CrossRef]

19. Barbotin AL, Ballot C, Sigala J, Ramdane N, Duhamel A, Marcelli F, Rigot JM, Dewailly D, Pigny P, Mitchell V. The serum inhibin B concentration and reference ranges in normozoospermia. Eur J Endocrinol 2015;172:669-76. [CrossRef]

20. Ruiz Plazas X, Burgues Gasion JP, Ozonas Moragues M, Piza Reus P. Utility of inhibin $B$ in the management of male infertility. Actas Urol Esp 2010;34:781-7. https://pubmed.ncbi.nlm.nih.gov/20843455/

21. Manzoor SM, Sattar A, Hashim R, Farooq Ahmad Khan, Muhammad Younas, Asif Ali, et al. Serum inhibin B as a diagnostic marker of male infertility. J Ayub Med Coll Abbottabad 2012;24:113-6. https:// pubmed.ncbi.nlm.nih.gov/24669628/

22. Baker K, Sabanegh E Jr. Obstructive azoospermia: reconstructive techniques and results. Clinics (Sao Paulo) 2013;68:61-73. [CrossRef]
23. Chong YH, Pankhurst MW, McLennan IS. The Daily Profiles of Circulating $\mathrm{AMH}$ and INSL3 in Men are Distinct from the Other Testicular Hormones, Inhibin B and Testosterone. PLoS One 2015;10:e0133637. [CrossRef]

24. Dong ZY, Zhang RL, He ZX, Sun HC. Relationship between pathological alterations of spermatogenic impairment and serum inhibin B concentration in patients with azoospermia. Zhonghua Nan Ke Xue 2006;12:18-20, 24.

25. Brugo-Olmedo S, De Vincentiis S, Calamera JC, Urrutia F, Nodar F, Acosta AA. Serum inhibin B may be a reliable marker of the presence of testicular spermatozoa in patients with nonobstructive azoospermia. Fertil Steril 2001;76:1124-9. [CrossRef]

26. Klingmüller D, Haidl G. Inhibin-B in men with normal and disturbed spermatogenesis. Hum Reprod 1997;12:2376-8. [CrossRef]

27. Ilingworth PJ, Groome NP, Byrd W, Rainey WE, McNeilly AS, Mather JP, Bremner WJ. Inhibin-B: a likely candidate for the physiologically important form of inhibin in men. J Clin Endocrinol Metab 1996;81:1321-5. [CrossRef]

28. Erdemir F, Parlaktaş BS, Uluocak N. Prostatitlerin Patofizyolojisi, Tanısı, Tedavisi ve Değerlendirilmesindeki Yenilikler. Üroloji Bült 2007;18:147-55.

29. Li HJ, Xu P, Liu JS et al. Prevalence of chronic prostatitis and its effects on male infertility. Zhonghua Yi Xue Za Zhi 2004;84:369-71. https:// europepmc.org/article/med/15061985

30. Nicolas N, Michel V, Bhushan S, Wahle E, Hayward S, Ludlow H, et al. Testicular activin and follistatin levels are elevated during the course of experimental autoimmune epididymo-orchitis in mice. Sci Rep 2017;7:42391. [CrossRef] 